\begin{tabular}{ll|l} 
Case Reports in & \multicolumn{2}{c}{ Case Rep Gastroenterol 2016;10:668-673 } \\
\cline { 2 - 3 } Gastroenterology & $\begin{array}{l}\text { DOI: } 10.1159 / 000452207 \\
\text { Published onIIne: November 14, 2016 }\end{array}$ & $\begin{array}{l}\text { Published by S. Karger AG, Basel } \\
\text { www.karger.com/crg }\end{array}$ \\
\cline { 2 - 3 } & $\begin{array}{l}\text { This article is licensed under the Creative Commons Attribution-NonCommercial } 4.0 \\
\text { International License (CC BY-NC) (http://www.karger.com/Services/OpenAccessLicense). } \\
\text { Usage and distribution for commercial purposes requires written permission. }\end{array}$
\end{tabular}

\title{
Obscure Gastrointestinal Bleeding Due to a Small Intestinal Gastrointestinal Stromal Tumor in a Young Adult
}

\author{
Mami Yamamoto Kentaroh Yamamoto Hirotaka Taketomi \\ Fumio Yamamoto Hiroshi Yamamoto \\ Department of Surgery, Yamamoto Memorial Hospital, Imari, Japan
}

\section{Keywords}

Gastrointestinal stromal tumors $\cdot$ Young adult $\cdot$ Small bowel bleeding $\cdot$ Small bowel tumor

\begin{abstract}
The source of most cases of gastrointestinal bleeding is the upper gastrointestinal tract. Since bleeding from the small intestine is very rare and difficult to diagnose, time is required to identify the source. Among small intestine bleeds, vascular abnormalities account for 70$80 \%$, followed by small intestine tumors that account for $5-10 \%$. The reported peak age of the onset of small intestinal tumors is about 50 years. Furthermore, rare small bowel tumors account for only $1-2 \%$ of all gastrointestinal tumors. We describe a 29 -year-old man who presented with obscure anemia due to gastrointestinal bleeding and underwent laparotomy. Surgical findings revealed a well-circumscribed lesion measuring $45 \times 40 \mathrm{~mm}$ in the jejunum that initially appeared similar to diverticulosis with an abscess. However, the postoperative pathological diagnosis was a gastrointestinal stromal tumor with extramural growth.
\end{abstract}

(C) 2016 The Author(s)

Published by S. Karger AG, Basel 


\section{Introduction}

Gastrointestinal (GI) bleeding is a common emergency [1] and bleeding from the upper GI tract and small intestine account for $75 \%$ and 2-10\% [1] of all GI bleeds [2], respectively. We describe a 29-year-old man who presented with obscure anemia due to small intestine bleeding. Vascular abnormalities account for $70-80 \%$, followed by small intestinal bleeds that account for $5-10 \%$, respectively [3].

Adenocarcinoma is the most common primary malignant tumor of the small bowel (PMTSB) [4, 5]. However, our patient had a gastrointestinal stromal tumor (GIST), which accounts for $<1 \%$ of all GI neoplasms [6]. The peak age for developing GIST is 50-60 years $[6,7]$, and thus GIST is rarely the source of small intestinal bleeds. This report describes obscure GI bleeding due to GIST of the jejunum of a young adult.

\section{Case Report}

A 29-year-old man presented to our hospital with a 2-week history of gross hematochezia and anemia. He was free of nausea, vomiting and localized abdominal pain. Laboratory findings were as follows (values are shown with range in parentheses): aspartate aminotransferase, 11 (normal, 5-35) U/L; alanine aminotransferase, 11 (5-30) U/L; alkaline phosphatase, 185 (115-359) U/L; $\gamma$-glutamyl transferase, 49 (0-50) U/mL; lactate dehydrogenase, 96 (106-211) U/L; albumin, 3.0 (3.7-5.5) g/dL; total bilirubin, 0.26 (0.2-1.0) g/dL; and C-reactive protein, $1.2(0-0.3) \mathrm{mg} / \mathrm{dL}$. Other than C-reactive protein, almost all blood biochemistry findings were essentially within normal ranges. Hematological findings were as follows (values are shown with range in parentheses): white blood cells, 11,600 (5,0008,000)/ $\mu \mathrm{L}$; red blood cells, $165(400-530) \times 10^{4} / \mu \mathrm{L}$; and hemoglobin, $4.5(14-18) \mathrm{g} / \mathrm{dL}$.

These findings indicated inflammation and anemia. Tumor markers were as follows (values are shown with range in parentheses): CEA $<0(0-5) \mathrm{ng} / \mathrm{mL}$; CA19-9, $3(0-37)$ $\mathrm{U} / \mathrm{mL})$; and IL-2, 280 (145-519) U/mL. All tumor markers were within normal ranges.

Upper GI endoscopy and total colonoscopy findings were normal. Abdominal computed tomography revealed a well-delineated $45 \times 40-\mathrm{mm}$ mass in the jejunum (Fig. 1). These findings indicated infected diverticulitis such as Meckel's diverticulitis with abscess [8].

The lesion in the jejunum was resected and removal of a possible tumor was assured by lymphadenectomy (Fig. 2). Thereafter, a jejuno-jejunostomy proceeded. The postoperative course was uneventful and the patient was discharged on postoperative day 10 .

The resected specimen initially appeared similar to diverticulosis with abscess, so we diagnosed infected diverticulosis (Fig. 3). However, the pathological findings revealed GIST with extramural growth. Histopathological assessment revealed a submucosal tumor comprising proliferative atypical spindle or epithelioid cells arranged in fascicle whorls with a dense acute inflammatory infiltrate, abscess and necrosis. Immunohistochemical findings showed that the atypical cells were positive for c-kit, and some were faintly positive for CD34 and S-100 (Fig. 4). The MIB-1 labeling index was $<1 \%$. These features were compatible with those of low-risk GIST [8-10]. 


\section{Discussion}

GI bleeding is a common medical emergency $[1,2]$. Accurate, prompt diagnosis of a bleeding source is crucial because such bleeding can result in death. The source of $3-5 \%$ of GI bleeds cannot be identified by esophagogastroduodenoscopy and/or colonoscopy, but bleeding from the upper and lower GI tracts accounts for 75 and 15\%, respectively, of all GI bleeds [1, 7]. The reported rate of bleeding from the small intestine is $2-10 \%$ [1]. Vascular abnormalities and small intestinal tumors account for $70-80 \%$ and $5-10 \%$, respectively, of small intestinal bleeds [3] and PMTSB accounts for only 1-2\% of all primary GI tumors $[11,12]$.

Most patients with PMTSB have nonspecific clinical symptoms and signs. The most frequent symptoms are abdominal pain (67.4\%), abdominal mass (31.2\%) and bowel obstruction $(24.1 \%)$, followed by hematochezia (21.3\%), jaundice (16.3\%), and fever (14.2\%) [4]. Our patient had only hematochezia.

Adenocarcinoma is the most common type of PMTSB [4, 5]. Leiomyoma and leiomyosarcoma in the small intestine are associated with massive bleeding, whereas lymphoma, GIST and carcinoids are associated with relatively slow bleeding [4, 7]. Our patient had a 2-week history of gross hematochezia and his condition roughly corresponded to GIST.

Mazur et al. [13] originally described GIST in 1983. Less than $1 \%$ of all GI neoplasms are GIST [6], and they are defined as specific, generally Kit (CD117)-positive and/or plateletderived growth factor receptor- $\alpha$ mutation-driven tumors $[9,10,13]$. Among mesenchymal tumors of the GI tract, GIST are the most common, and primary GIST can occur anywhere along the GI tract between the esophagus and the anus. Between 50 and $70 \%$ of clinically manifested tumors arise in the stomach, $20-30 \%$ are found in the small bowel, 5-15\% are located in the large bowel, and $<5 \%$ are located in the esophagus and elsewhere [14]. The reported peak age of GIST is 50-60 years [6,7]. Therefore, to initially consider GIST in a differential diagnosis of GI bleeding in a younger patient is unlikely.

Meckel's diverticulum and Crohn's disease are common when considering only GI bleeds in younger patients. Meckel's diverticulum is the most common congenital anomaly of the GI tract, with an incidence of $2-4 \%$ in the general population. Meckel's diverticulum occurs twice as often in men than in women, and acute diverticulitis can occur at any age, but the incidence peaks in children $[15,16]$. Meckel's diverticulum is always located within $1 \mathrm{~m}$ of the oral side of the ileocecal valve and straying ectopic stomach tissue is the key pathological feature in $27 \%$ of patients with this disease [16]. The specimen resected from our patient macroscopically resembled diverticulitis, but it was not obtained from a location within $1 \mathrm{~m}$ from the oral side of the ileocecal valve. Small intestinal diverticula other than the Meckel type can be differentially diagnosed, but the incidence ranges from only 0.06 to $1.3 \%$ [17]. Finally, microscopic assessment ruled out these types of diverticulosis.

Crohn's disease is also common among younger patients. Crohn et al. [18] first described this condition in 1932 as a chronic inflammatory disease of unknown origin that can occur not only in the terminal ileum but anywhere in the GI tract. It commonly affects men and women aged in the early 20s and late teens, respectively [18-20]. Preoperative upper and lower GI endoscopy and pathological findings excluded Crohn's disease as the bleeding source in our patient. 


\section{Conclusion}

We described hemorrhage due to GIST of the small intestine in a young adult male. The possibility of neoplastic disease must be considered even among young adults who present with GI bleeding.

\section{Statement of Ethics}

Written informed consent was obtained from the patient for publication of this paper and any accompanying images. All authors read and approved the final manuscript.

\section{Disclosure Statement}

The authors have no conflicts of interest to disclose.

\section{References}

1 Manning-Dimmitt LL, Dimmitt SG, Wilson GR: Diagnosis of gastrointestinal bleeding in adults. Am Fam Physician 2005;71:1339-1346.

-2 Geffroy Y, Rodallec MH, Boulay-Coletta I, Julles MC, Ridereau-Zins C, Zins M: Multidetector CT angiography in acute gastrointestinal bleeding: why, when, and how. Radiographics 2011;31:E35-E46. Szold A, Katz LB, Lewis BS: Surgical approach to occult gastrointestinal bleeding. Am J Surg 1992;163:90-92.

-4 Han SL, Cheng J, Zhou HZ, Guo SC, Jia ZR, Wang PF: Surgically treated primary malignant tumor of small bowel: a clinical analysis. World J Gastroenterol 2010;16:1527-1532.

5 Hatzaras I, Palesty JA, Abir F, Sullivan P, Kozol RA, Dudrick SJ, et al: Small-bowel tumors: epidemiologic and clinical characteristics of 1,260 cases from the Connecticut tumor registry. Arch Surg 2007;142:229-235.

6 Nowain A, Bhakta H, Pais S, Kanel G, Verma S: Gastrointestinal stromal tumors: clinical profile, pathogenesis, treatment strategies and prognosis. J Gastroenterol Hepatol 2005;20:814-824.

7 Nakatani M, Fujiwara Y, Nagami Y, Sugimori S, Kameda N, Machida H, et al: The usefulness of doubleballoon enteroscopy in gastrointestinal stromal tumors of the small bowel with obscure gastrointestinal bleeding. Intern Med 2012;51:2675-2682.

-8 Erol V, Yoldaş T, Cin S, Çalışkan C, Akgün E, Korkut M: Complicated Meckel's diverticulum and therapeutic management. Ulus Cerrahi Derg 2013;29:63-66.

-9 Hirota S, Isozaki K, Moriyama Y, Hashimoto K, Nishida T, Ishiguro S, et al: Gain-of-function mutations of c-kit in human gastrointestinal stromal tumors. Science 1998;279:577-580.

10 Scherübl H, Faiss S, Knoefel WT, Wardelmann E: Management of early asymptomatic gastrointestinal stromal tumors of the stomach. World J Gastrointest Endosc 2014;6:266-271.

-11 Jemal A, Siegel R, Ward E, Hao Y, Xu J, Murray T, et al: Cancer statistics, 2008. CA Cancer J Clin 2008;58:71-96.

12 DiSario JA, Burt RW, Vargas H, McWhorter WP: Small bowel cancer: epidemiological and clinical characteristics from a population-based registry. Am J Gastroenterol 1994;89:699-701.

13 Mazur MT, Clark HB: Gastric stromal tumors. Reappraisal of histogenesis. Am J Surg Pathol 1983;7:507519.

-14 Alvardo-Cabrero I, Vázquez G, Sierra Santiesteban FL, Hernández-Hernández DM, Pompa AZ: Clinicopathologic study of 275 cases of gastrointestinal stromal tumors: the experience at 3 large medical centers in Mexico. Ann Diagn Pathol 2007;11:39-45.

15 Robijin J, Sebrechts E, Miserez M: Management of incidentally found Meckel's diverticulum a new approach: resection based on a Risk Score. Acta Chir Belg 2006;106:467-470.

16 Chen JJ, Lee HC, Yeung CY, Chan WT, Jiang CB, Sheu JC, et al: Meckel's diverticulum: factors associated with clinical manifestations. ISRN Gastroenterol 2014;2014:390869.

-17 Staszewicz W, Christodoulou M, Proietti S, Demartines N: Acute ulcerative jejunal diverticulitis: case report of an uncommon entity. World J Gastroenterol 2008;14:6265-6267. 


\section{Case Reports in Gastroenterology}

\begin{tabular}{l|l}
\hline Case Rep Gastroenterol 2016;10:668-673 \\
\hline DOI: 10.1159/000452207 & $\begin{array}{l}\text { @ 2016 The Author(s). Published by S. Karger AG, Basel } \\
\text { www.karger.com/crg }\end{array}$ \\
\hline
\end{tabular}

Yamamoto et al:: Obscure Gastrointestinal Bleeding Due to a Small Intestinal Gastrointestinal Stromal Tumor in a Young Adult

18 Crohn BB, Ginzburg L, Oppenheimer GD: Regional ileitis: a pathologic and clinical entity. 1932. Mt Sinai J Med 2000;67:263-268.

19 Morita N, Toki S, Hirohashi T, Minoda T, Ogawa K, Kono S, et al: Incidence and prevalence of inflammatory bowel disease in Japan: nationwide epidemiological survey during the year 1991. J Gastroenterol 1995;30:1-4.

20 Yao T, Matsui T, Hiwatashi N: Crohn's disease in Japan: diagnostic criteria and epidemiology. Dis Colon Rectum 2000;43:S85-S93.

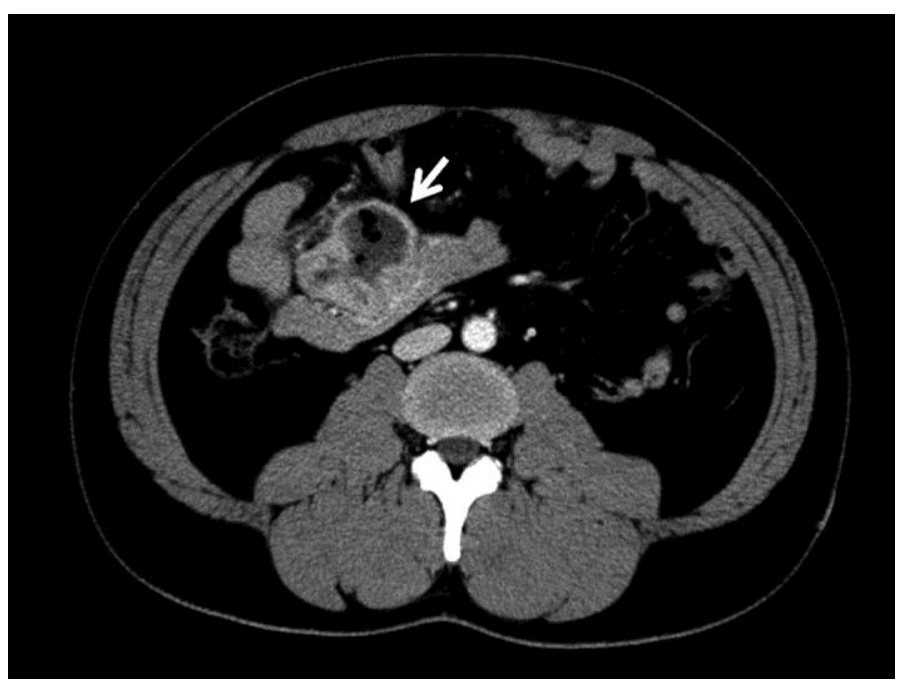

Fig. 1. Computed tomography findings. White arrow, well-delineated $45 \times 40$-mm mass in the jejunum.

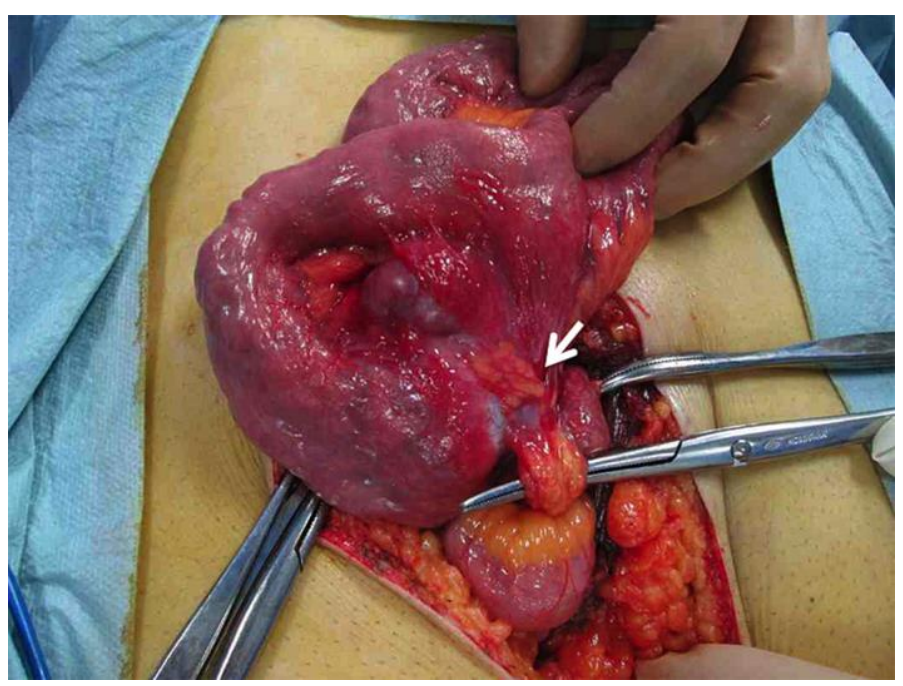

Fig. 2. Intraoperative view. White arrow, well-circumscribed $45 \times 40$-mm lesion with inflammatory adhesion. 


\section{Case Reports in \\ Gastroenterology}

\begin{tabular}{l|l}
\hline Case Rep Gastroenterol 2016;10:668-673 \\
\hline DOI: 10.1159/000452207 & $\begin{array}{l}\text { @ 2016 The Author(s). Published by S. Karger AG, Basel } \\
\text { www.karger.com/crg }\end{array}$ \\
\hline
\end{tabular}

Yamamoto et al:: Obscure Gastrointestinal Bleeding Due to a Small Intestinal Gastrointestinal Stromal Tumor in a Young Adult
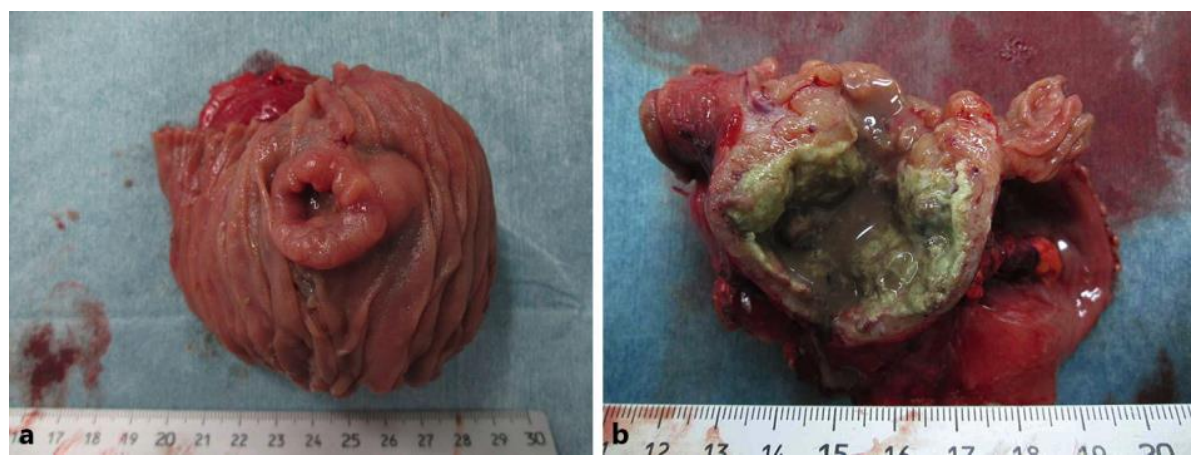

Fig. 3. Resected specimen. a Dissected jejunum shows swollen diverticulosis. b Cross-sectional slice shows infected diverticulosis with abscess. Pathological findings revealed GIST with extramural growth.
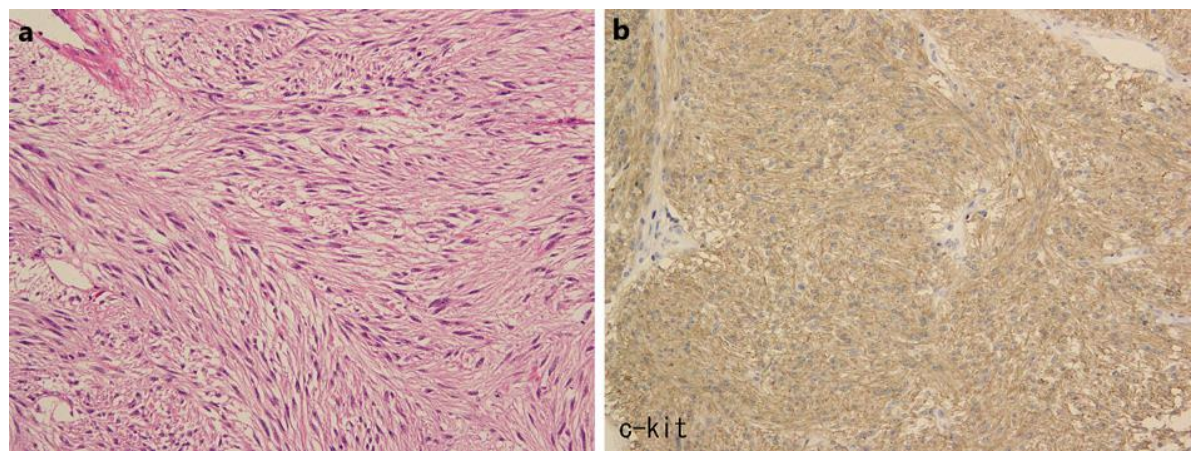

Fig. 4. Pathological examination of the tumor. a The tumors consisted of spindle cells (hematoxylin and eosin staining, $\times 100)$. b Immunohistochemically, the atypical cells positively reacted to c-kit $(\times 100)$. MIB-1 labeling index was $<1 \%$. 